\title{
Health Locus of Control and Self Care Behavior in Patients with Type 2 Diabetes Mellitus
}

\author{
Siti Aisyah Dwi Asri ${ }^{1}$, Nur Widayati ${ }^{*}$, and Latifa Aini $\mathbf{S}^{\mathbf{3}}$ \\ 1Puskesmas Prajekan, Bondowoso, Jawa Timur, Indonesia \\ 2,3Faculty of Nursing, University of Jember \\ Jl. Kalimantan No. 37 Kampus Tegal Boto Jember, Jawa Timur, Indonesia \\ *Correspondence: nur_wida.psik@unej.ac.id \\ Type of the Paper (Article)
}

Received: July 29, 2020; Accepted: August 20, 2020; Published: September 5, 2020

https://doi.org/10.29253/achnr.2020.22249

\begin{abstract}
Health Locus of Control (HLC) is an individual belief in controlling current health conditions, which is possibly determined by internal or external factors. Belief in the source of health control will influence the effectiveness of diabetes self-care management. This study aimed to analyze the correlation between Internal Health Locus of Control (IHLC), Powerful others Health Locus of Control (PHLC), and Chance Health Locus of Control (CHLC) with self-care behavior in type 2 diabetes mellitus patients. This research applied an observational analytic design with a cross-sectional approach. A total of 84 respondents were enrolled in this study by using the consecutive sampling technique. Data collection was conducted by administering questionnaires of the Multidimensional Health Locus of Control Scale (MHLCS) and Summary of Diabetes Self Care Activities (SDSCA). Data were analyzed by using the Pearson correlation test with a significance level of 0.05. The result showed that PHLC had the highest score of the mean value (26.95) compared to IHLC (25.55) and CHLC (19.25). The mean value of self-care behavior was 3.5. There was significant positive correlation between IHLC and self-care behavior (p-value: 0.001; r: 0.485), significant negative correlation between PHLC and self-care behavior ( $p$-value: 0.048; r: -0.217), and significant negative correlation between CHLC and self-care behavior ( $\mathrm{p}$-value: $0.001 ; \mathrm{r}:-0.350$ ). The higher the IHLC score in type $2 \mathrm{DM}$ patients, the better the patient's self-care behavior. However, the higher the PHLC or CHLC score in type 2 DM patients, the lower the patient's self-care behavior. Patients with high IHLC depend on themselves and have awareness of the importance of health. This study suggests the importance of assessing the patient's HLC and providing psychoeducation about HLC, control behaviors, and self-awareness to optimize diabetes self-care in type 2 diabetes mellitus patients.
\end{abstract}

Keywords: type 2 diabetes mellitus, health locus of control, self-care behavior

\section{Introduction}

Diabetes Mellitus (DM) is not only a disease problem for citizens in developed countries but also a problem for citizens in developing countries including Indonesia. This disease no longer dominates the old age group, but the younger age group (Fitri, 2015). DM is a group of metabolic disorders characterized by hyperglycemia that occurs due to abnormalities in insulin secretion, insulin action, or both (American Diabetes Association $[\mathrm{ADA}], 2010)$. If the disease is left without taking preventive actions or appropriate 
treatments, it will result in complications that can be a serious threat to diabetes patients, namely blindness, kidney failure, and diabetic foot ulcer (gangrene) (Indonesia Departement of Health, 2013).

Data on the incidence of DM according to the International Diabetes Federation ([IDF], 2015) states that in 2015 there were 415 million people diagnosed with diabetes worldwide. Indonesia ranks 7 th as the largest number of people with diabetes in the world in 2015. There are 10 million cases of diabetes incidence in Indonesia aged 20-79 years (IDF, 2015). The prevalence of diagnosed diabetes in East Java is $2.1 \%$. The results of basic health research show that residents in rural areas diagnosed with DM are almost the same as those in urban areas (Indonesia Ministry of Health, 2013).). According to data from the Jember Regency Health Office, the number of DM patient visits to the Public Health Center in the Jember Regency area from January to November 2016 was recorded as many as 9,982 visits.

DM is a complex chronic disease that requires continuous treatment. According to the World Health Organization ([WHO], 2016) states that a simple lifestyle such as maintaining ideal body weight, continued physical activity, diet, and avoiding smoking is proven to be more effective in preventing diabetes and delaying complications. Therefore, effective diabetes management is needed, one of which is self-care behavior such as diet control, glycemic control, foot care, and regular exercise (Kusniawati, 2011). However, previous studies have shown that self-care performed by diabetes patients is still not optimal. Kusniawati's research (2011) shows that the average value of self-care performed by DM patients is 4.9 days a week. The results of this study indicate that each diabetes self-care activity has not been fully implemented, namely 7 days a week. Research by Maghfirah et al. (2015) showed that the level of self-care behavior of diabetes patients was moderate (60\%). The results of research by Desalu et al. (2011) on 352 respondents showed 174 respondents (49.4\%) had bad practices in diabetic foot care.

Health Locus of Control (HLC) is a person's degree of confidence whether their health is controlled by internal or external factors (Khatoon, 2012). Locus of control is classified into an internal locus of control which consists of internality and external locus of control which consists of Powerful Others and Chance (Levenson 1973 in Lefcourt (1981). When a person has an internal locus of control (IHLC), they believe that the source of control of reinforcement is completely dependent on oneself which will produce certain behaviors in accordance with their expectations. Someone who has a powerful others locus of control, they believe that the source of control of reinforcement is entirely dependent on the strength of others which will produce certain behaviors in accordance with their expectations. Likewise, someone who has a locus of control chance, they believe that the source of control of reinforcement is completely dependent on luck, fate or destiny which in turn will produce certain behaviors according to their expectations. People with external locus of control, either powerful others or chance, they believe that they are powerless against outside forces (Schultz \& Schultz, 2005).

In a study by Nawafa'h and Mansour (2015) in type 2 DM patients, there was a significant and positive relationship between HLC and self-efficacy with the highest average score being on the Powerful others Health Locus of Control (PHLC) of 30.9 which indicates the patient believes that their health outcomes depend on others rather than themselves or because of luck. In the study of Abredari et al. (2015) found a direct relationship between Internal Health Locus of Control (IHLC) and diabetic foot selfcare ( $\mathrm{p}<0.001)$, which means that patients believe that their role in their health is correlated with higher scores in diabetic foot self-care. Besides, there is an inverse relationship between PHLC with diabetic foot self-care and Chance Health Locus of Control (CHLC) with diabetic foot self-care.

Research conducted by Safitri (2013) regarding dietary adherence of type 2 DM patients in terms of locus of control shows that respondents who have IHLC have high adherence compared to subjects who have powerful others locus of control and chance locus of control. A person with IHLC will tend to work hard to take measures to recover, trying to find solutions to problems. Someone with external HLC (powerful others or chance) will be more passive because they believe that external factors control them (Adnyani et al., 2015). Based on the background, the researcher conducted a study on the relationship between HLC and self-care behavior in type 2 DM patients.

\section{Literature Review}

\section{Health Locus of Control}

Locus of control refers to an individual's condition that links their success and failure. When a person perceives the locus of control in himself, it will result in greater achievement in their life because their potential can be utilized so that they become more creative and productive (Forte, 2005). Rotter 
(1966) defines a locus of control as to whether individuals believe that situations or events that occur under their control will influence their expectations and behavior. Robbins and Judge (2009) define the locus of control as the degree to which individuals believe that they are determinants of their destiny. Locus of control is a personality variable defined as an individual's belief in his or her ability to control one's fate. Individuals who have the belief that fate or events in their life are under their control are said to have an internal locus of control. Meanwhile, individuals who have the belief that the environment has control over fate or events that occur in their life are said to be individuals who have an external locus of control (Suls \& Wallston, 2003).

The definition of HLC is the extent to which people believe that their health state can be controlled (Eachus, 1991). HLC is a person's belief that their health can be controlled (Wallston, et al., 1978 in Grifka \& Harris, 2000). HLC is a person's degree of confidence whether their health is controlled by internal or external factors (Khatoon, 2012). According to Wallston, Stein, \& Smith (1994) stated that HLC refers to a person's beliefs about their health control. If people believe that their own behavior affects their health status, then that person is said to have an internal locus of control orientation. However, if a person believes that his health status is influenced by the actions of others or because of fate, luck, or chance, then that person is said to have an external locus of control orientation.

Locus of control has been used to investigate health-related behaviors (Wallston \& Wallston, 1978). According to Rotter (1966) in Schultz \& Schultz (2005) explains locus of control as a stable variable that has two dimensions, namely internal locus of control and external locus of control. In terms of internal locus of control, the belief that success is worth the effort and is largely derived from self-control. Individuals with a tendency for internal locus of control believe that the events experienced are the result of their own behavior and actions, have good control over their own behavior, tend to be able to influence others, actively seek information and knowledge regarding the situation at hand. On the other hand, in terms of external locus of control, the belief that their actions have little impact on their success or failure and that few of them can change it. Individuals with external locus of control believe that the power of others, destiny, and opportunity are the main factors controlling their own behavior, tend to be influenced by others, often do not believe that their efforts can be successful, and are less active in seeking information and knowledge related to situations faced. According to Levenson 1973 in Lefcourt (1981) Individuals who are oriented to an internal locus of control are more confident that the events experienced in their lives are mainly determined by their abilities and efforts. Individuals with the orientation of powerful others locus of control believe that their lives are determined by the more powerful people around them, while those who are the chance locus of control-oriented believe that life and events experienced are largely determined by destiny, fate, luck, and opportunity.

\section{Self-Care Behavior}

Self-care is defined as a form of one's behavior in maintaining health, development, and surrounding life (Baker \& Denyes, 2008). Based on the Self Care Nursing Theory by Dorothea Elizabeth Orem, selfcare is the patient's ability to carry out self-care activities to improve and maintain health independently so that patients can meet their needs (Potter \& Perry, 2005). Self-care is an act created for oneself or the environment that contributes to the maintenance of the functions of the human body for the continuation of life, health, and well-being. Self-care action is a response to the functional needs of humans both subjective and objective needs (Renpenning \& Taylor, 2003: 103). According to DeLaune \& Ladner (2002), self-care is a learned behavior and action or response to a need.

Diabetes self-care is a program or action that must be carried out throughout the patient's life and is the full responsibility of every diabetic patient (Bai et al., 2009). Self-care in DM patients focuses on four aspects, namely monitoring blood glucose levels, variations in nutrients consumed every day, insulin regulation, and regular physical exercise (Sigurdardottir, 2005). According to the American Association of Diabetes Education ([AADE], 2014) defines self-care behavior as a framework for diabetes patients centered on Diabetes Self-Management Education (DSME) and care. Seven self-care behaviors are effective in diabetes self-management, namely healthy eating, being active, monitoring, taking medication, problem-solving, healthy coping, and reducing risk.

Healthy eating refers to a variety of foods for a balanced diet and includes healthy food, selection of the right foods, ideal portion sizes, and frequency of meals. Being active is meant to be active in doing physical activities such as exercises and sports. Being more active by doing physical activity can lose weight, burn calories, strengthen muscles and bones, lower blood sugar levels, lower cholesterol levels, 
maintain blood pressure, reduce stress, and change the mood for the better (AADE, 2014). According to ADA (2010) physical activity recommended for DM patients is light exercise such as walking for 30 minutes 3-5 times a week and according to Continuous, Rhythmical, Interval, Progressive, Endure training (CRIPE).

Monitoring blood sugar levels regularly is an important part of management for DM patients. Monitoring blood glucose levels can be done independently. Self Monitoring Blood Glucose (SMBG) plays a role in maintaining normalization of blood glucose and allows patients to detect and prevent hyperglycemia and hypoglycemia to reduce long-term diabetic complications (Smeltzer \& Bare, 2001). Monitoring blood sugar depends on the type of diabetes. Blood sugar monitoring can be done several times a week or three times a day and it takes two hours after eating to monitor blood sugar levels. Blood sugar levels will rise and fall during the day depending on how much the patient does activity and diet (AADE, 2014).

Untreated diabetes can increase the risk of complications, such as heart or kidney problems, so the use of appropriate drugs for DM patients is needed to reduce blood sugar levels. The use of drugs for DM patients is very much needed and requires assistance to avoid overdose or the side effects of the opposite drug (Sustrani, Alam, Hadibroto, 2004). Recognizing the risk of diabetes early can help type 2 DM patients in preventing complications that can occur at any time. Reducing the risk of complications can be done by maintaining blood sugar within normal limits, checking cholesterol and blood pressure, avoiding smoking, taking health checks or controls to a doctor, visiting a dentist, and performing foot care (AADE, 2014).

Some of the problem-solving skills for diabetic patients are learning how to recognize and react to high or low blood sugar levels and how to manage them when they are sick. Problem-solving can help type $2 \mathrm{DM}$ patients to prepare for the unexpected and be able to plan for similar problems in the future. DM can affect health physically and emotionally. Living with diabetes can make the patient feel discouraged, stressed, and even depressed. Healthy coping methods that can be used to overcome this are being able to participate in sports, religion, meditation, and hobbies (AADE, 2014).

\section{Methodology}

The research design was analytic observational with a cross-sectional approach. The sampling technique was consecutive sampling. The research was conducted in April 2017. The population of the study was type 2 DM patients recorded in Public Health Center (PHC) of Patrang, Jember; that was 255 people. Determination of the number of samples using the $\mathrm{G}^{*}$ Power 3 application (effect size: $0.30 ; \alpha$ : 0.05; and power: 0.80 ) so that as many as 84 people were obtained as the sample. The inclusion criteria included patients who have been diagnosed with type 2 DM for at least 6 months, aged 30-65 years, able to communicate well, and willing to participate. The exclusion criteria were patients who have physical limitations such as blindness or deafness, have comorbidities, such as stroke, heart disease, diabetic foot ulcers, experience severe physical disturbances or conditions of discomfort that are unlikely to continue the study, such as acute hyperglycemic complications, hyperosmolar hyperosmolar coma (HHNK), diabetic ketoacidosis, and have severe mental disorders such as Alzheimer's or dementia assessed by Mini-Mental State Examination (MMSE).

Data collection was performed by administered the Multidimensional Health Locus of Control Scale (MHLCS) Form C and Summary Diabetes Self Care Activity (SDSCA). The MHLCS questionnaire was compiled by Wallston, Wallston, and Devellis in 1978 which consists of three forms, namely forms A, B, and $C$. This questionnaire contains a series of questions regarding three subscales, namely internal health locus of control, powerful others health locus of control, and chance health locus of control. The questionnaire used by the researchers was form $\mathrm{C}$ which was specifically used in patients with certain (chronic) disease conditions. The MHLCS Form C instrument was also used by researchers Nawafa'h and Mansour in 2015 on type 2 DM patients. This questionnaire consists of 18 statements, each of which contains 6 statements on the internal subscale, 6 statements on the chance subscale, and 6 subscales on the powerful others. (Wallston, Stein, \& Smith, 1994). Respondent scores for each HLC subscale are obtained by adding up the statement scores on the subscale so that the lowest score is 6 and the highest score is 36 . The scores obtained from the three dimensions differ theoretically and empirically, cannot be combined into a single score but must be evaluated separately so that there is no total score from all dimensions (Wallston, Wallston, and Devellis, 1978). The MHLCS Form C instrument has been translated 
into Indonesian by researchers through the Language Center of University of Jember. After that, standard sentence corrections in Indonesian were made by the Indonesian Language Course Instructors at the Faculty of Cultural Sciences, University of Jember. This instrument has a validity test value on each subscale of IHLC, PHLC, CHLC was in the range of 0.500-0.774; 0.432-0.803; 0.587-0.764 consecutively. The Cronbach Alpha value was 0.703; 0.715; and 0.791 consecutively.

The SDSCA questionnaire was developed by Toobert, Hampson \& Glasgow (2000) and has been translated into Indonesian by Kusniawati in 2011. This questionnaire consists of 14 questions related to diabetes self-care activities. This instrument consists of 8 alternative answers, namely 0 to 7 days. The value of the respondents is obtained by adding up the values of all questions divided by 14 . The lowest score is 0 and the highest is 7 . The instrument that has been translated and modified has a validity test value in the range of $0.200-0.743$ with $r$ table $=0.361$ which means valid. The Cronbach's Alpha reliability value of the SDSCA instrument is 0.812 which means reliable.

Data analysis used Pearson correlation test with a significant level of 0.05 to determine the relationship between HLC and self-care behavior in type 2 DM patients. This study was preceded by giving informed consent to respondents. Researchers also maintain confidentiality, act fairly, and do not harm respondents. The research was carried out based on a permit from the Nursing Faculty, University of Jember (number 1071 / UN25.1.14 / LT / 2017), the Research Institute of University of Jember (number 0390 / UN25.3.1 / LT / 2017), the National Unity and Politics Office of Jember Regency (number 072/2398/314/2017), Jember Regency Health Office (number 440/15108/311/2017), and Public Health Center of Patrang, Jember Regency (number 440/130 / 311.06 / 2017).

\section{Results}

Characteristics of Respondents

Table 1. Characteristic of Respondents (n: 84).

\begin{tabular}{lcc}
\hline Variable & Mean & SD \\
\hline Age & 54.76 & 7.01 \\
Diabetes Duration & 2.88 & 2.08 \\
Variable & $\mathbf{n}$ & $\mathbf{\%}$ \\
\hline Gender & & \\
Male & 31 & 36.9 \\
Female & 53 & 63.1 \\
$\quad$ Total & 84 & 100 \\
Marital status & & \\
Single & 0 & 0 \\
Married & 84 & 100 \\
$\quad$ Total & 84 & 100 \\
Education Level & & \\
None & 2 & 2.4 \\
Elementary School & 27 & 32.1 \\
Junior High School & 21 & 25.0 \\
Senior High School & 23 & 27.4 \\
University & 11 & 13.1 \\
$\quad$ Total & 84 & 100 \\
Occupation & & \\
None & 2 & 2.4 \\
Civil servant & 10 & 11.9 \\
Farmer & 1 & 1.2 \\
Private employees & 13 & 15.5 \\
Entrepreneur & 18 & 21.4 \\
Housewife & 34 & 40.5 \\
Lain-lain & 6 & 7.1 \\
Total & 84 & 100 \\
\hline
\end{tabular}


Table 1 shows the mean age of the respondents is 54.76 years ( $\mathrm{SD}=7.01)$. The average length of experiencing diabetes is 2.88 years $(\mathrm{SD}=2.08)$. The distribution of respondents according to gender is more female than male. Of the 84 respondents, all are married. The most recent education level is an elementary school (32.1\%). Most respondents occupation is housewives (40.5\%).

\section{Health Locus of Control}

Table 2 shows that the highest mean value of HLC is on the PHLC subscale, namely 26.95 (SD = 3.87), followed by IHLC with a mean value of $25.55(\mathrm{SD}=4.30)$ and the lowest value on CHLC with a mean value of $19,25(\mathrm{SD}=5.65)$.

Table 2. Mean Value of Health Locus of Control.

\begin{tabular}{lcc}
\hline Variable & Mean & SD \\
\hline IHLC & 25.55 & 4.30 \\
PHLC & 26.95 & 3.87 \\
CHLC & 19.25 & 5.65 \\
\hline
\end{tabular}

\section{Self-Care Behavior}

Table 3 shows that the mean value of self-care behavior in type 2 DM patients is 3.5 days a week (SD $=0.93$ ). The highest mean value of self-care behavior is on the medication management indicator, namely 5.6 days a week $(\mathrm{SD}=2.6)$. The lowest mean value is on the indicator of blood glucose testing, namely 0.8 days a week $(\mathrm{SD}=1.0)$.

Table 3. Mean Value of Self Care Behavior.

\begin{tabular}{lcc}
\hline Variable & Mean & SD \\
\hline Self Care Behavior & 3.5 & 0.93 \\
Diet & 4.6 & 1.4 \\
Physical Activity & 2.0 & 1.9 \\
Blood Glucose Testing & 0.8 & 1.0 \\
Medication Management & 5.6 & 2.6 \\
Foot care & 2.6 & 1.6 \\
\hline
\end{tabular}

Analysis of the Relationship between HLC and Personal Care Behavior

Table 4 shows the results of the analysis of the relationship between HLC in each of the three subscales and self-care behavior. The results show that there is a significant and positive relationship with a moderate degree $(r=0.485$; $\mathrm{p}<0.05)$ between IHLC and self-care behavior. Besides, there is a significant and negatively correlated relationship with a weak level on the PHLC subscale with self-care behavior $(r=-0.217$; $\mathrm{p}<0.05)$ and on the CHLC subscale with self-care behavior $(r=-0.350 ; p<0,05)$.

Tabel 4. Analysis of the Relationship between HLC and Personal Care Behavior.

\begin{tabular}{lcc}
\hline Variable & r & $\boldsymbol{p}$ value \\
\hline IHLC & 0.485 & 0.001 \\
Self Care Behavior & & \\
PHLC & -0.217 & 0.048 \\
Self Care Behavior & & 0.001 \\
CHLC & -0.350 & \\
Self Care Behavior & & \\
\hline
\end{tabular}

\section{Discussion}

\section{Health Locus of Control}

HLC consists of three subscales namely IHLC, PHLC, and CHLC. HLC is a person's degree of confidence whether their health is controlled by internal or external factors (Khatoon, 2012: 61). The concept of HLC is part of the social learning theory by J. Rotter in 1996 and the variable expectancy plays a role in determining health behavior (Pervin, 1984 in Smet, 1994: 181; Khatoon, 2012). Social learning theory influences health through the learning process. Each individual will develop the belief that the results obtained are an act of himself or outside of himself (Rotter, 1966 in Schultz \& Schultz, 2005). HLC also plays an important role and influence in determining health behavior. After a person has a locus of 
control (LOC) and has expectations that will result in strengthening and knowing the source of strengthening from internal or external, he will be motivated to behave as predicted in certain situations (Rotter 1966; Khatoon, 2012; Grifka, 2000: 96; Djiwandono, 2002: 181).

In this study, each respondent has all three HLC subscales. The average IHLC value for all respondents is 25.55 , the average PHLC value is 26.95 , and the average CHLC value is 19.25 . The results of this study are in line with the research of Nawafa'h \& Mansour (2015) in type 2 DM patients in Amman, Jordan, the average score for the IHLC subscale was 27.2, for the PHLC subscale was 30.9, and for the CHLC subscale was 18.6. Based on the results of these two studies, it was found that the three subscales showed the highest average value on the PHLC subscale and the lowest average value on the CHLC subscale. These results indicate that patients have the belief that their health outcomes depend more on the strengths of others (powerful others) such as health professionals, family, and friends more than themselves or luck. Besides, patients also believe that chance has a minimal role in determining or controlling their health. PHLC refers to an individual's belief about the current health status achieved, depending on the strength behavior of others such as the competence of doctors, behavior of family members, friends, and the environment, whereas CHLC refers to an individual's belief that coincidence factors determine health outcomes (Rotter, 1966; Wallston, Wallston, \& DeVellis, 1978).

Respondents to the current study showed the highest score on the PHLC subscale which means that patients are more confident that health is achieved because of control than the strengths of others. Based on the theory that in general, Asians are shown to be more externally oriented than Americans, this is based on a finding that is explained in terms of cultural beliefs. American culture is more towards independence and individualism while Asian culture emphasizes community dependence and interdependence. Therefore, for Asians, success is seen more as a product of external rather than internal factors (Schultz \& Schultz, 2005).

However, different results obtained in the study of Aflakseir \& Abadi (2016) in chronic disease patients in Shiraz, Iran showed that the higher score was in IHLC $(M=23.15)$, followed by PHLC (M = 17.62) and CHLC $(M=15.25)$. The results of this study are in line with the study of Morowatisharifabad (2009) in type 2 DM patients in Iran who had the highest score on IHLC with an average of 26.6, followed by PHLC with an average of 23.2 and CHLC with an average of 9.4. . Likewise, research by Petricek et al. (2008) in DM patients who are Croatian nationalities in Europe, showed that most of the patients had high IHLC, followed by PHLC and CHLC. The three studies above show that the highest average score is on the IHLC subscale, even though the research subjects in the Aflakseir \& Abadi (2016) and Morowatisharifabad (2009) study come from the same continent, namely Asia. The results are the same as the research of Petricek et al. (2009) whose research subjects came from Europe who has in common, namely the highest average score is on the IHLC subscale. This proves that culture can influence LOC, but that does not mean that a person's culture can always determine the type of LOC (Otterman, 1999).

Apart from culture, LOC can also be influenced by age, gender, and education. In the current study, the average age of the respondents was 54.76 and there were more women than men, this could affect the respondents' HLC. Following the theory by Rotter in 1966, he found that age affects an individual's LOC. It is shown that a person's IHLC will increase with age (Schultz \& Schultz, 2005). The more mature a person is, the LOC develops internally and is stable in middle age (Englar in Ghufron \& Risnawati, 2010). Furthermore, according to Sukma (2012), a person's LOC will become more external from adulthood to old age. In this study, it was found that the PHLC score was higher than the IHLC score because the number of male respondents might have been less than that of women. This is supported by the research of Morowatisharifabad et al. (2009) showed that men have higher scores on IHLC than women. These results have been proven in current studies which show that the mean IHLC score of men is greater than that of women. Besides, it could be possible in this study because the number of respondents with the highest education, namely college was less than respondents with primary and secondary education. The research of Hayes et al. (2000) showed that the lower the patient education, the higher the powerful others score and chance. This has been proven in this study that respondents with a higher level of education, namely universities, have a higher IHLC average score than the dimensions of PHLC and CHLC compared to respondents with primary and secondary education.

\section{Self-Care Behavior}

Diabetes self-care is a program or action that must be carried out throughout the patient's life and is the full responsibility of every diabetic patient (Bai et al., 2009). Self-care for DM clients is a very 
important activity. This is consistent with the statement that self-care in DM patients can prevent morbidity and mortality (La Greca et al., 2005). Patients who are aware of self-care activities will prove better diabetes management (Heisler et al., 2004 in Kusniyah, et al., 2010). Increased diabetes self-care activities have an impact on improving the health status of diabetes patients because it can control diabetes and prevent diabetic complications (Xu et al., 2008).

Diabetes self-care behavior in type 2 diabetes mellitus patients in the work area of Puskesmas Patrang, Jember Regency in this study includes diet planning, physical exercise, blood sugar monitoring, drug management, and foot care. The results of the current study found that the mean value of self-care behavior in type 2 DM patients is 3.5 days a week, which means that every diabetes self-care activity has not been fully implemented 7 days a week. The self-care behavior that is still not fully carried out 7 days a week is also found in a study by Kusniawati (2011), it was found that the average diabetes self-care activities were 4.9 days a week. Likewise, research by Besen et al. (2016) on 129 people with type 2 diabetes mellitus in Turkey showed the frequency of self-care activities in the past week was 2.9 days. Self-care behavior that is not done properly will cause increased glucose levels. This is evidenced in the study of Sigurdardottir (2005) which states that ignoring self-care or low self-care shows low HbA1c value. Besides, according to Abredari et al. (2015) stated that lower self-care, the risk of experiencing complications such as diabetic foot ulcers. This is in line with Mahfud's (2012) research, where there is a significant relationship between foot care for type $2 \mathrm{DM}$ patients with the incidence of diabetic ulcers.

The low self-care indicates that there are factors that affect Type 2 DM patients in carrying out their care (Sari, 2013). According to Sigurdardottir (2005), it is known that one of the factors that influence self-care is knowledge. This is evidenced in Ismonah's (2008) study showing that low knowledge has an impact on low glucose control. Apart from knowledge, the level of education also affects low self-care. The level of education can reflect a person's intellectual abilities. This is in line with the research of Desalu et al. (2011) showed that low education, namely primary schooling, was significantly associated with low scores for foot care knowledge and practice. Most of the respondents in this study have a primary school education, so it is possible that low self-care behavior can be influenced by low education.

Apart from the factors described above, several factors influence the low self-care behavior, namely age, family social support, and emotional aspects. Kusniawati's research (2011) shows that age has a positive relationship with diabetes self-care, the older you get, the more rational your mindset will be about diabetes self-care. According to Ismonah (2008), age affects the ability to do self-care management of DM. As a person gets older, the ability is getting better and begins to decrease when he enters the elderly stage. According to Skinner \& Hampson (2000), family and friends support is a better predictor of doing a self-care diet. According to Kusniawati (2011) states that emotional problems such as stress, boredom with regimens, and worry can affect self-care. This is in line with Sigurdardottir (2005) who showed that emotional aspects were significantly related to diabetes self-care behavior. Emotionally heavy patients had fewer self-care scores while patients without emotional problems had improved selfcare.

The diabetes self-care behavior that had the highest average score was drug management with an average score of 5.6 days a week. This result is similar to Kusniawati's (2011) research, where the highest average self-care score is on the indicator of taking medication, namely 6.7 days per week. One of the factors that influence patients to comply with medication is patient knowledge. According to Kusniawati (2011), the reason patients take medication regularly is that patients already understand the importance of taking these actions in diabetes self-management. Patients know the meaning, causes, treatment of diabetes, and how to control blood sugar levels so that patients take medication regularly.

However, sometimes there are several factors from patients choosing to rely on taking medication due to the inability to perform physical activities, as stated by diabetes patients in the study of Mathew et al. (2012). Utomo's research (2011) shows that people who have adherence to taking medication have a 4 times risk of being successful in managing type 2 diabetes mellitus compared to those who are not adherent and it is statistically significant. According to Dailey et al. (2001) stated that the number of drugs consumed also influenced patient medication adherence. Patients who were prescribed one type of drug had better adherence than patients who were prescribed two or more drugs. The frequency of taking medication also becomes a factor that affects patient compliance in regulating diabetes patient medication (Widayati, 2015). 
In the research of Khattab et al. (2010) in type 2 diabetes mellitus patients showed that the majority of patients (91.9\%) were very adherent to their treatment. Patients were said to be very adherent if they had never missed their treatment in the previous 7 days. Therefore, medication adherence is important to optimize the outcome of DM management (Michael Ho et al., 2006). This is in line with the research of Salistiyaningsih (2011) which states that there is a significant relationship between patients who are compliant and non-adherent in taking oral hypoglycemic drugs (OHO) and the blood glucose levels of Type 2 DM patients, namely patients who are adherent have normal blood glucose levels and nonadherent patients have high blood glucose levels.

The indicator with the lowest average value on diabetes self-care behavior is the indicator of blood sugar testing at health services and independently at home, which is 0.8 , which means that patients have their blood sugar checked on average once a week. These results are in line with Pranata's research (2016) showing that the lowest average self-care is on the indicator of blood sugar testing, namely 0.82 . Likewise, Kusniawati's research (2011) shows that the average value of respondents monitoring blood sugar is 1.0 days a week. Blood sugar monitoring is not carried out properly because patients do not have a device to check their blood sugar personally, they only check their blood sugar when they go to health services, and check their blood sugar at the nearest pharmacy if their condition is felt sick. The activity of checking blood sugar tests at home and in health services is an important part of controlling blood sugar and diabetes independently. According to Tomky \& Albuquerque (2010), Self Monitoring Blood Glucose (SMBG) is intended for diabetic patients to check blood glucose independently at home with a glucometer. Therefore, it is very important for DM patients to monitor at any time with a glucometer because blood glucose levels always change during the day and night.

Another reason that it may be possible for patients not to have regular blood sugar checks is due to the cost factor. This is in accordance with a research by Widayati (2015) on type 2 DM patients carried out in the working area of the Jember Kidul Community Health Center, Jember Regency, it was found that the need for expensive costs and transportation to visit and check sugar levels to health service facilities were taken into account by participants in doing check-ups and blood sugar checks. The cost of monitoring blood sugar has become a major burden for patients with limited economic conditions (Karter et al., 2000). Checking blood sugar levels regularly is an evaluation of eating patterns, physical exercise, and taking the medication regularly. Patients with type 2 diabetes are allowed to measure blood sugar levels independently at least two to three times per week (Brunner \& Suddarth, 2009 in Kusniawati, 2011).

Low research results were also found on indicators of physical activity and foot care. The average value on the indicators of physical activity is 2.0 days a week and foot care is 2.6 days a week. Foot care measures and inadequate physical activity in this study were due to the patient's lack of awareness of the importance of foot care and physical activity to prevent diabetes complications such as diabetic ulcers. Besides, most patients think that if they have adjusted their diet, their blood sugar levels will be well controlled.

According to AADE (2014) doing physical activity can strengthen muscles and bones, lose weight, blood sugar levels, blood pressure, cholesterol, and reduce stress. Physical activity recommended for DM patients is light exercise such as walking that lasts 30 minutes 2-5 times a week (ADA, 2015). Meanwhile, according to Austin (2005) physical, environmental, and psychological conditions can become obstacles in carrying out physical activity. Widayati's research (2015) states that the factors that can reduce patients to do physical activity are laziness and a lack of self-confidence which is expressed in the form of helplessness and feelings of hopelessness. Therefore, it is necessary for health workers to increase motivation and self-confidence of type 2 DM patients by providing structured health education and facilitating the provision of social support in carrying out physical activities in the home environment.

Low foot care indicators are also caused by a lack of knowledge and self-efficacy. In the research of Li et al. (2014) showed a positive relationship between knowledge and foot care behavior, which means that the better the knowledge, the better foot care. Research Sa'adah \& Primanda (2016) there is a positive relationship between self-efficacy and foot care behavior, which means that the higher the selfefficacy, the better the DM foot care behavior. According to Mayfield et al (2000), foot examination at least once a year is recommended for all diabetic patients to identify high risks such as peripheral vascular insufficiency, deformity of the leg structure, and loss of sensation as protection. Therefore, it is important for nurses to provide access to health education regarding foot care such as the need to be 
taught how to choose the right footwear to protect the feet and prevent trauma to the feet, pay attention to water temperature, and maintain skin moisture and explain the serious complications that can arise due to improper foot treatment (Li et al., 2014; Widayati, 2015).

\section{The Relationship of IHLC with Self-Care Behavior}

The results of statistical tests showed a relationship between IHLC and self-care behavior in type 2 diabetes mellitus in the work area of Puskemas Patrang, Jember Regency. IHLC with self-care behavior has a significant relationship with a moderate correlation level the correlation value is positive. The correlation value is positive, which means that the higher the IHLC score in type 2 DM patients, the higher the patient's self-care behavior. These results suggest that type 2 DM patients believe that their role in their health is correlated with higher scores in diabetes self-care behavior. The results of this study are in line with the research of Morowatisharifabad et al. (2009) found a positive relationship between IHLC and adherence to the diabetes regimen, meaning that the higher the IHLC score, the higher the diabetes regimen adherence score in diabetic patients.

Diabetes patient self-management education is very important to prevent acute complications and reduce the risk of long-term complications (ADA, 2014). Therefore, diabetes management is needed for diabetes patients, one of which is self-care behavior. If self-care behavior is not carried out properly, patients will be at risk of experiencing complications such as diabetic foot ulcers. For self-care behavior to be carried out properly, self-confidence is needed in type 2 DM patients. Self-confidence in the effectiveness of DM management is a factor that affects clients in carrying out diabetes self-care, especially diet, exercise, and blood sugar monitoring (Piette et al, 2003). Based on this statement, previous research found that there was a significant and positive relationship between IHLC and diabetic foot self-care (Abredari et al., 2015). Based on the results of current research and supporting previous studies, it can be seen that IHLC plays an important role in determining self-care in DM patients.

IIHLC is one of the dimensions of HLC proposed by Wallston, Wallston, \& DeVellis in 1978 which refers to the social learning theory by J. Rotter in 1996. IHLC is the belief that an individual's health status is influenced and can be controlled by their own choices and behavior. According to Comer (1998) in Iskandarsyah (2006) states that IHLC is considered more beneficial for individual health. This is because IHLC is a person's belief that their health search results are related to their behavior or investment (Sasagawa et al., 2008). By the concept of social learning theory by J. Rotter in 1966, when a person has an internal locus of control, they believe that the source of control of reinforcement is completely dependent on himself which will produce certain behaviors following their expectations. They also have a strong grip on their situation and will behave in accordance with the situation (Schultz \& Schultz, 2005: 432). Someone who has the perception that all things happen because of his self-control will have a high expectancy. If it is assumed to be under the 1966 Rotter formula, a behavior potential will be formed if one expectation or reinforcement value is high, then the potential behavior will be higher so that it can be seen that people who have a high IHLC score are likely to believe that the source of control of their health comes from the control in themselves. high. This makes the person have high hopes of being healed or healthy so that they lead to better behavior.

Based on the prediction of the Rotter formula, it is found that individuals who believe that the events experienced are a result of their own behavior and actions, have good control over their own behavior, tend to be able to influence others, actively seek information, and knowledge regarding the situation (Schultz \& Schultz, 2005). This opinion is in accordance with the research of Septiady et al. (2015) stated that higher IHLC correlates with higher life satisfaction, desire to control health services, increased seeking information related to health behavior, more compliance with health recommendations, and increased activity. Individuals with IHLC will have an awareness of the importance of health (Comer, 1998 in Iskandarsyah, 2006; Safitri, 2013). This is because individuals who have IHLC believe that the disease that occurs to them is purely from their own fault, not from external factors such as a disaster, unfortunate fate, or people around them who do not pay attention to their health. The disease that occurs to him is due to a lack of control from within himself so that when he feels pain, it is because of the individual himself who does not pay attention to his health (Safitri, 2013).

Research by Cheng et al. (2016) found that stronger IHLC-oriented individuals were associated with greater involvement in two health-enhancing behaviors, namely exercise, and diet. Exercise and diet are included as indicators of diabetes self-care behavior. An exercise is a form of routine activity. If patients don't do sports, the pancreas is no longer sensitive in secreting insulin which causes blood sugar to 
remain high. This statement is in line with the research of Ayele et al. (2014) which states that regular exercise can lower blood glucose levels and help control diabetes. Research by Cobb-Clark et al. (2014) found that individuals with internal LOC were more likely to exercise well and exercise regularly. In addition to previous studies that found a relationship between IHLC and physical activity. It was also found that in a study conducted by Safitri (2013) in patients with type 2 diabetes, it was found that there was a significant difference in adherence in terms of LOC where research subjects who had IHLC had high adherence to treatment. A study by Popova (2012) found that IHLC determines a higher level of health. Therefore, encouraging the patient to be more internal will increase healthy behaviors such as physical activity and decrease mortality (Langer, 1983 in Eachus, 1991). According to Adnyani (2015) health workers can provide education to patients about the importance of self-control of their health conditions so that patients are expected to form internal beliefs and change behavior for the better. Based on this, it is expected that health workers will know the patient's HLC so that they can make adjustments in providing health services.

Based on the results of this study, it can be seen that IHLC has a positive correlation with diabetes self-care behavior. This is because individuals with high IHLC, strengthening completely depend on themselves and raise a sense of awareness of the importance of health so that it will lead to good selfcare behavior. Therefore, it can be seen that having an internal source of control over health status also plays a role in increasing self-care behavior.

The existence of a moderate level of correlation obtained in this study is possible because of the factors that exist within individuals who believe that their health status is controlled by internal factors such as a sense of awareness that can improve self-care behavior. Another factor that can improve patient self-care behavior is age. The average age of the respondents is 54.76 years old, which is included in middle adulthood which can be related to the level of thinking maturity. According to Potter \& Perry (2005), the older the people, the higher the ability to assess themselves. The number of respondents who were half women in this study can also influence self-care behavior. According to Sousa et al. (2005) stated that women seem to care more than men about their health so that they make optimal efforts to perform self-care. Work can also influence self-care behavior. In this study, it was found that most jobs were housewives who could possibly contribute to increasing self-care behavior. This can be explained in the research of Jadawala et al. (2017) showed that patients with housewives were twice as likely to adhere to diet activities due to more experience and knowledge on how to create a healthy diabetes diet.

\section{Relationship between PHLC and Self Care Behavior}

The results of statistical tests showed that there was a relationship between PHLC and self-care behavior in type $2 \mathrm{DM}$ in the work area of Puskemas Patrang, Jember Regency. PHLC and self-care behavior has a significant relationship with a weak correlation level and the correlation value is negative. The correlation value is negative, which means that the higher the PHLC score in type 2 DM patients, the lower the patient's self-care behavior, which means that the patient believes that the role of health professionals, family, and the surrounding environment on their health is correlated with lower scores in self-care behavior. This explains that patients perceive health professionals, family, and the environment to have an important role and a big control for their health, compared to controls from within themselves. Patients also assume that the health condition to be achieved, whether it is cured or the condition gets worse, all depends on other people who play a role, so that patients will not perform self-care if other people do not remind patients to do self-care activities.

Similar to IHLC, PHLC is one of the dimensions of HLC proposed by Wallston, Wallston, \& DeVellis in 1978 which refers to the social learning theory by J. Rotter in 1996. PHLC is the belief that health status can be controlled and depends on the competence of doctors, the behavior of family members, etc. (Wallston, Wallston, \& DeVellis, 1978). Someone who has a high PHLC believes that the source of reinforcement control is entirely dependent on the strength of others which will later produce certain behaviors in accordance with their expectations (Schultz \& Schultz, 2005).

People see the situation they are experiencing at this time due to external factors such as other people who have more power over them. People who have the perception that everything happens because of other people's strengths and not their self-control are likely to have low expectancy. In accordance with the Rotter 1966 formula, a behavior potential will be formed if one of the expectations or reinforcement values is low, then the potential behavior will be lower. However, when a person responds to reactions from the surrounding environment with a good perceptual pattern and learns from 
past experiences of his disease, it will reinforce him, thus creating good expectancy and potentially good behavior (Rotter, 1966).

Research by Morowatisharifabad et al. (2009) in Iranians demonstrated that powerful others locus of control was not significantly associated with adherence to diabetes regimens. Based on the results of these studies, it can be seen that a person with a high PHLC score will lead to a lack of healthy behaviors such as low diabetes self-care behavior, lack of physical activity, and non-adherence to the regimen. This is because someone with PHLC tends to depend on other people. If they fall sick, they will blame others for their illness. While other people (family, friends, and closest people) do not necessarily understand the conditions that occur to them and what they need (Wallston, Wallston, \& DeVellis, 1978). This dependence will have an impact on making someone passive. in the research of Adnyani et al., (2015) which states that individuals with external HLC will be more passive, have less initiative, seek less information to solve problems, and do not like to try because individuals believe that external factors control them.

The results of the current study are in line with research by Abredari et al. (2015) showed an inverse relationship between PHLC and diabetic foot self-care. A person who has a high PHLC score and low selfcare behavior put that person at risk for diabetes complications. Reducing the risk of complications can be done by maintaining blood sugar within normal limits, carrying out medical examinations or controls to a doctor, and performing foot care (AADE, 2014).

However, there are different results in the study of Taher et al., (2015) in hypertensive patients who showed that people with PHLC had controlled blood pressure and reported better adherence to treatment regimens. The results of other studies conducted by Zahednezhad et al. (2011) found that there was a positive correlation between PHLC and treatment adherence in diabetes patients. The results of the study were different between those of Abredari et al. (2015) with Taher et al., (2015) \& Zahednezhad et al. (2011), based on the belief of someone who has a high PHLC, namely individuals who are oriented to an external locus of control, powerful others believe that a disease that comes to them is from external factors. He thought that people in his environment, such as family, medical personnel had an important role in his health. Individuals with a powerful others locus of control orientation are very dependent on other people, they believe that medical personnel can heal them more than they believe in self-control (Safitri, 2013). However, if the disease does not heal immediately, then they will blame the doctor who did not properly administer the medicine or other people who did not provide support in the treatment even though what happened was the result of irregularity in taking the medicine (Abredari et al., 2015). From this explanation, it can be seen that a person with high PHLC will respond positively or negatively to their health in accordance with the psychological situation and the surrounding environment.

A person must have support, confidence, and self-care ability to improve their health status because this is the main key in improving the quality of life of patients with chronic diseases (Bowen et al. 2015). The support that can be provided to patients is family social support. Families who accompany patients can provide care and affection, help assess problems, and plan things that can be done to solve problems so that patients will feel lighter in dealing with their illness (ADA, 2015). Therefore, education is needed on the importance of family social support to the patient's family to improve the ability to self-care behavior.

\section{Relationship between CHLC and Self-Care Behavior}

The results of statistical tests showed that there was a relationship between CHLC and self-care behavior in type 2 DM in the work area of Puskemas Patrang, Jember Regency. CHLC and self-care behavior has a significant relationship with a weak correlation level and the correlation value is negative. The correlation value is negative, which means that the higher the CHLC score in type 2 DM patients, the lower the patient's self-care behavior. This study is in line with the research of Abredari et al. (2015) there is an inverse relationship between CHLC and diabetic foot self-care. Another research that supports the research of Morowatisharifabad et al. (2009) found that there was a negative relationship between CHLC and adherence to the diabetes regimen. Based on current and previous studies, a person with a high CHLC score may be likely to adversely influence healthy behavior, namely self-care behavior, diabetic foot care behavior, and low adherence to diabetes regimens.

Self-care behavior in DM clients plays an important role in the management of DM, especially in preventing diabetic complications (La Greca et al, 2005). In addition to diabetic complications, low selfcare for people with Type 2 diabetes will affect the patient's quality of life and have an impact on the 
patient's psychological stress (Kusniawati, 2011). Clients who experience stress are usually due to client non-compliance. Factors that influence client noncompliance are negative attitudes from family, attitudes of health workers, and individual beliefs. Faith contributes to health (Iswanti, 2012).

HLC is a person's belief that their health can be controlled. CHLC is one of the dimensions of HLC which refers to the social learning theory by J. Rotter in 1966. (Wallston, Wallston, \& DeVellis, 1978; Grifka \& Harris, 2000). CHLC is a person's belief that the source of reinforcement control completely depends on fate, destiny, or luck as a factor that controls their health which will result in certain behaviors in accordance with their expectations (Schultz \& Schultz, 2005: 432). Various studies have been conducted to find out that CHLC plays a role in healthy behavior. In the study of Grotz et al. (2011) found that someone who has high scores on the CHLC dimension tends to do less exercise, has fewer health programs, and is less systematic in seeking information.

A person with CHLC tends to be indifferent in paying attention to health and give up on himself, leading to an unhealthy lifestyle and do whatever he pleases. If they fall sick, they will think that it is time to get sick (Wallston, Wallston, \& DeVellis, 1978). The surrender attitude of the individual is caused by the individual perceiving the situation he is currently experiencing due to a disaster which according to him cannot be changed so that he assumes that everything that happens is destiny, not his poor selfcontrol or his environment. Someone who has the perception that all things happen because of fate and not control of himself or his environment will have low expectancy (Rotter, 1966; Wallston, Wallston, \& DeVellis, 1978). In accordance with the Rotter 1966 formula, behavior potential will be formed if one expectation or reinforcement value is low, then the potential behavior will be lower so that it can be seen that people who have a high CHLC score are likely to believe that the source of control over their health comes from fate or luck, which makes people have a reduced hope of recovery or health, leading to worse behavior.

In this study, it was shown that CHLC was negatively correlated with self-care possibly because the source of reinforcement control was entirely dependent on fate, destiny, or luck as control over its health. Reinforcement that is completely dependent on destiny will later result in low expectancy and reinforcement of health because the patient thinks that something is happening is not his self-control, leading to low self-care behavior.

In this study, it was found that a weak relationship indicated that CHLC did not play too big a role in the low score of self-care behavior. The resigned attitude of patients with higher CHLC scores indicates that the patient's ability to solve problems is still lacking. Meanwhile, according to AADE (2014) states that problem-solving is needed for type $2 \mathrm{DM}$ patients because it can help prepare for unexpected things and be able to plan for similar problems in the future. This will affect health physically and emotionally. Emotional changes can affect self-care behavior. Patients who have heavy emotional have fewer self-care scores while patients without emotional problems have increased self-care (Sigurdardottir, 2005).

The number of respondents with low education in this study was more than that of tertiary education, namely the upper secondary level and higher education, which may influence self-care behavior. Research by Desalu et al. (2011) showed that low education resulted in low knowledge of foot care. In this study, it was found that the average value of the duration of experiencing diabetes was 2.88 years, whose duration was still said to be short when compared to the duration of more than 5-10 years so the value of patient self-care might have been still low. This is because according to research by Bai et al. (2009) showed that patients with longer DM duration had higher self-care scores than patients with shorter DM duration. This is related to the patient's learning experience regarding the disease and previous treatment (Chen et al., 1998). Based on the explanation above, the emotional aspects, age, knowledge, education, and duration of experiencing DM are several other factors that may affect the low self-care in DM patients in this study.

\section{Conclusion}

Based on the results of this study, it can be concluded that there is a significant relationship between the three HLC subscales, namely IHLC, PHLC, and CHLC with self-care behavior in type 2 DM patients in the work area of Public Health Center of Patrang, Jember Regency. However, on the PHLC and CHLC subscales, there is a negative relationship with self-care behavior, while on the IHLC subscale there is a positive relationship with self-care behavior. 
The relationship in this study shows that a person must have confidence in the source of health control to improve diabetes self-care behavior. Therefore, it is hoped that health workers will assess the patient's HLC and change the patient's control to be more positive so that they can play an active role in self-care. The application of HLC can be combined by providing psychoeducation to patients and their families. Future studies are expected to use probability sampling techniques and examine other factors that influence the low self-care behavior of type 2 DM patients.

\section{References}

Abredari, H., Bolourchifard, F., Rassouli, M., Nasiri, N., Taher, M., \& Abedi, A. (2015). Health locus of control and selfcare behaviors in diabetic foot patients. Medical Journal of the Islamic Republic of Iran (MJIRI). 29:283.

Adnyani, I. A. P. S., Widyanthari, D. M., \& Saputra, K..( 2015). hubungan health locus of control dengan kepatuhan penatalaksanaan diet DM Tipe 2 di Paguyuban DM Puskesmas III Denpasar Utara. COPING Ners Journal. $3(3): 75$.

Aflakseir, A. A., \& Abadi, M. S. M. (2016). The role of health locus of control in predicting depression symptoms in a sample of Iranian older Adults with Chronic Diseases. Iran J Psychiatry. 11(2): 82-86.

American Diabetes Association (ADA). (2010). Standards of Medical Care in Diabetes-2010. http://www.diabetes.org/diabetes-basics/statistics/ [Retrieved 2 October 2016].

American Diabetes Association (ADA). (2014). Statistics about diabetes. predictor of self-care in adolenscent with cystic fibrosis: a test of orem's theories of self-care and self care defisit. $h t t p: / / w w w . d i a b e t e s . o r g$ [Retrieved 2 October 2016].

American Association of Diabetes Educators (AADE). (2014). AADE7 $7^{\text {TM }}$ Self-Care Behaviors. https://www.diabeteseducator.org/patient-resources/aade7-self-care-behaviors/ [Retrieved 2 October 2016].

Austin, M. M. (2005). Importance of self-care behaviors in diabetes management. http://www.touchbriefings.com/pdf/1479 /austin_bookforweb.pdf [Retrieved 29 July 2017].

Ayele, K., Tesfa, B., Abebe, L., Tilahun, T., dan Girma, E. (2014). Self care behavior among patients with diabetes in Harari, eastern ethiopia: the health belief model perspective. PLoS ONE . 7(4): e35515- . doi: 10.1371/journal.pone.0035515

Bai, Y. L., Chiou, C. P., \& Chang, Y. Y. (2009). Self-care behaviour and related factors in older people with type 2 diabetes. Journal of Clinical Nursing. 18: 3308-3315. doi:10.1111/j.1365-2702.2009.02992.x

Baker, L.K. \& Denyes, M. J. (2008). Predictors of self-care in adolescents with cystic fibrosis: a test of orem's theories of self-care and self-care deficit. Journal of Pediatric Nursing. 23(1): 37.

Besen, D. B., Gunusen, N., Surucu, H. A., \& Kosar, C. (2016). Predictor effect of Locus Of Control (LOC) on self-care activities and metabolic control in individuals with type 2 diabetes. PeerJ. 4: 1-17. Doi: 10.7717/peerj.2722

Bowen, P.G, O. J. Clay, L. Lee, J. Vice, F. Ovalle, dan M. Crowe. 2015. Associations of social support and self-efficacy with quality of life in older adults with diabetes. Journal of Gerontological Nursing, 20, 1-10. Doi: 10.3928/00989134-20151008-44

Chen, Z. T., Chang, M \& Lin, Y. C. (1998). The relationship between self efficacy, social support and self-care behaviors in diabetes mellitus patients. Journal of Nursing Research. 6:31-42.

Cheng, C., Cheung, M. W. L., \& Lo, B. C. Y. (2016). Relationship of health locus of control with specific health behaviours and global health appraisal: a meta-analysis and effects of moderators. Health Psychology Review. 10(4): 460-477. Doi: http://dx.doi.org/10.1080/17437199.2016.1219672.

Cobb-Clark, D. A., Kassenboehmer, S. C., \& Schurer, S. (2014). Healthy habits: the connection between diet, exercise, and locus of control. Journal of Economic Behavior \& Organization. 98: 1-28. Doi: http://dx.doi.org/10.1016/j.jebo.2013.10.011.

Dailey, G., Kim, M. S.,\& Lian, J. F. (2001). Patient compliance and persistence with antihyper-glycemic drug regimens: evaluation of a medicaid patient population with type 2 diabetes mellitus. Clinical Therapeutics. 23:13111320.

DeLaune, S. C. \& Ladner, P. K. (2002). Fundamentals of Nursing: Standart and Practise. $2^{\text {nd }}$ Ed. New York: Thomson Delmar Learning.

$\begin{array}{llllll}\text { Djiwandono, } & \text { S. } & \text { E. } & \text { W. } & 2002 . & \text { Psikologi }\end{array}$ https://books.google.co.id/books?id=TNs2aM5LqKQC\&printsec=frontcover\&dq [Retrieved 12 January 2017].

Desalu, O. O., Salawu, F. K., Jimoh, A. K., Adekoya, A. O., Busari, O. A., \& Olokoba A. B. (2011). Diabetic foot care: self reported knowledge and practice among patients attending three tertiary hospital in Nigeria. Ghana Medical Journal. 45(2): 59.

Eachus, P. 1991. Multidimensional health locus of control in nurse. Journal of Advanced Nursing. 16: 165-171. 
Fitri. 2015. Data prevalensi penderita diabetes di Indonesia. http://sehat.link/data-prevalensi-penderita-diabetesdi-indonesia.info [Retrieved 24 September 2016].

Forte, A. 2005. Locus of control and the moral reasoning of managers. Journal of Business Ethics. 58: 65-77.

Ghufron, M. N. \& Risnawati, R. (2010). Teori-Teori Psikologi. Jogjakarta : Ar-Ruzz Media Group.

Grifka, J. \& Harris, D. J. O. (2000). Ostheoarthritis Fundamental and Strategies for Joint-Preserving Treatment. https://books.google.co.id/books?id=wWYlBAAAQBAJ\&pg=PA197\&lpg=PA197\&dq [Retrieved 11 January 2017]

Grotz, M., Hapkeb, U., Lampertb, T., \& Baumeistera, H. (2011). Health locus of control and health behaviour: results from a nationally representative survey. Psychology, Health \& Medicine. 16(2): 129-140.

Hayes, R. P., Benard, A. M., Slooum, W., El-Kebbi, I., Zlemer, D., Gallina, D., \& Phillips L. S. 2000. Diabetes in urban African Americans assesment of diabetes-specific locus of control in patients with type 2 diabetes. The Diabetes Educator. 26(1): 121-128

International Diabetes Federation (IDF). (2015). Diabetes Atlas, Indonesia. http://www.idf.org/membership/wp/indonesia [Retrieved 24 September 2016].

Indonesia Departement of Health. (2013). Diabetes Melitus Penyebab Kematian Nomor 6 Di Dunia : Kemenkes Tawarkan Solusi Cerdik Melalui Posbin. http://www.depkes.go.id/article/view/2383/diabetes-melituspenyebab-kematian-nomor-6-di-dunia-kemenkes-tawarkan-solusi-cerdik-melalui-posbindu.html [Retrieved 2 October 2016].

Indonesia Ministry of Health. (2013). Riset 2013. http://www.depkes.go.id/resources/download/general/Hasil\%20Riskesdas\%202013.pdf [Retrieved 24 September 2016].

Iskandarsyah, A. (2006). Hubungan antara Health Locus of Control dan Tingkat Depresi pada Pasien Gagal Ginjal Kronis di RS. NY. R. A. Habibie Bandung. Bandung: Fakultas Psikologi Universitas Padjajaran.

Ismonah. (2008). Analisa faktor-faktor yang mempengaruhi perawatan diri pasien diabetes melitus tipe 2 di Kecamatan Medan Johor. Tesis. Jakarta: FIK UI

Iswanti, D. I. (2012). Pengaruh terapi perilaku modeling partisipan terhadap kepatuhan minum obat pada klien penatalaksanaan regimen teraupetik tidak efektif di RSJD Dr. Amino Gondo Hutomo Semarang. Tesis. Jakarta: FIKUI

Jadawala, H. D., Pawar, A. B., Patel, P. B., Patel, K. G., Patel, S. B., \& Bansal, RK. (2017). Factors associated with nonadherence to diet and physical activity among diabetes patients: a cross sectional study. National Journal of Community Medicine. 8(2):68-73

Karter, A. J., Ferrara, A., Darbinian, J. A., Ackerson, L. M., \& Selby, J. V. (2000). Self-monitoring of blood glucose: language and financial barriers in a managed care population with diabetes. Diabetes Care. 23: 477-483. http://care.diabetesjournals.org/content/23/4/477.full.pdf [Retrieved 4 June 2017].

Khattab. M., Khader, Y. S., Al-Khawaldeh, A., \& Ajlouni, K. (2010). Factors associated with poor glycemic control among patients with Type 2 diabetes. Journal of Diabetes and Its Complications. 24: 84-89. doi:10.1016/j.jdiacomp.2008.12.008

Khatoon, N. (2012). Health Psychology. India: Dorsling Kindersley. https://books.google.co.id/books?id=v7b5ccQDQKwC\&pg=PA61\&lpg=PA61\&dq [Retrieved11 January 2017]

Kusniyah, Y., Nursiswati, \& Rahayu, U. (2010). Hubungan tingkat self care dengan tingkat hba1c pada klien diabetes melitus tipe 2 di poliklinik endokrin rsup dr. Hasan sadikin bandung. http://repository.unpad.ac.id/8976/1/hubungan_tingkat_self_care_dengan_tingkat_hba1c.pdf [Retrieved 22 May 2017].

Kusniawati. (2011). Analisis Faktor yang berkontribusi terhadap self care diabetes pada klien diabetes melitus tipe 2 di rumah sakit umum Tangerang. Skripsi. Depok: Fakultas Ilmu Keperawatan UI.

La Greca \& Annette, M. (2004). Self Care Inventory-Revised Version (SCI-R). (Online). http://www.psy.miami.edu/faculty/alagreca/SCI-R.pdf [Retrieved 22 May 2017].

Lefcourt, H. (1981). Differentiating Among Internality, Powerful Others, and Chance. New York: Academic Press.

Maghfirah, S., Sudianan, I. K., \& Widyawati, I. Y. (2015). Relaksasi otot progresif terhadap stres psikologis dan perilaku perawatan diri pasien Diabetes Mellitus Tipe 2. Jurnal Kesehatan Masyarakat. 10(2): 137-146.

Mahfud, M. U. (2012). Hubungan Perawatan Kaki Pasien Diabetes Melitus Tipe 2 dengan Kejadian Ulkus Diabetik di RSUD Dr. Moewardi. Skripsi. Surakarta: Fakultas Kedokteran, Universitas Muhammadiyah Surakarta.

Mathew, R., Gucciardi,E., Melo, M. D., \& Barata, P. (2012). Self-management experiences among men and women with type 2 diabetes mellitus: a qualitative analysis. BMC Family Practice. 13:122

Mayfield, J. A et al. 2000. Do foot examinations reduce the risk of diabetic amputation? Journal of family practice. 49: 499-504. http://www.ncbi.nlm.nih.gov/pubmed/10923547 [Retrieved 30 June 2017]. 
Michael Ho, P., Rumsfeld, J. S., Masoudi, F. A., McClure, D. L., Plomondon, M. E., Steiner, J. F. \& Magid, D. J. 2006. Effect of medication nonadherence on hospitalization and mortality among patients with diabetes mellitus. Arch Intern Med. 166(17):1836-1841. doi:10.1001/archinte.166.17.1836.

Morowatisharifabad, M., Mahmoodabad, M., Baghianimoghadam, M., \& Tonekaboni, R. (2009). Relationships between locus of control and adherence to diabetes regimen. J Res Health Sci. 9(1): 37-44. http://jrhs.umsha.ac.ir/index.php/JRHS/article/download/258/374 [Retrieved 3 April 2017].

Nawafa'h, D. N. A. \& Mansour, A. M. H. (2015). Correlates of health locus of control among patients diagnosed with type-II diabetes mellitus. Journal of Diabetes Mellitus. 5: 190-197.

Otterman, Y. (1999). The great culture debate: clearly not a black and white issue. https://www.units.miamioh.edu/psybersite/control/culture.shtml [Retrieved 28 May 2017].

Petricek, G., Nekic, V. C., Adzic, Z. O., Vuletic-Mavrinac, G., Soldo, D., Murgic, L., Tiljak, H., Gmajnic, R., \& Vrcic-Keglevic, M. (2008). Pp-283 health locus of control of diabetes mellitus type 2 patients. Wonca Europe World Family Doctors. http://www.woncaeurope.org/content/pp-283-health-locus-control-diabetes-mellitus-type-2patients [Retrieved 5 June 2017].

Petricek, G., Mavrinac,G., \& Keglevic, V. (2009). Health Locus of Control Assesment in Diabetes Mellitus Tipe 2 Patients. https://www.ncbi.nlm.nih.gov/pubmed/19580220 [Retrieved 23 May 2017].

Piette, J. D. \& Kerr, E. A. (2009). The impact of comorbid chronic conditions on diabetes care. Diabetes Care. 29:72531.

Popova, S. (2012). Locus of Control-Predictor of Health and Subjective Well-Being. European Medical, Health and Pharmaceutical Journal. Doi: http://dx.doi.org/10.12955/emhpj.v4i0.367

Potter, P. A. \& Perry, A. G. (2005). Buku Ajar Fundamental Keperawatan: Konsep, Proses, dan Praktik. Edisi 4. Volume 2. Terjemahan oleh : R. Komalasari, dkk. Jakarta: EGC.

Pranata, A. J. (2016). Hubungan Diabetes Distress dengan Perilaku Perawatan Diri pada Penyandang Diabetes Melitus Tipe 2 di Wilayah Kerja Puskesmas Rambipuji Kabupaten Jember. Skripsi. Jember: PSIK UNEJ.

Rotter, J. B. (1966). Generalized expectancies for internal versus external control of reinforcement. Psychological Monographs: General and Applied. 80(1).

Robbins, S. P. \& Judge, T. A. (2009). Organizational Behavior. 13 ${ }^{\text {th }}$ Edition. Pearson Education, Inc., Upper Saddle River, New Jersey.

Renpenning, K. M. \& Taylor. (2003). Self-care Theory In Nursing. New York: Springer Publishing Company, Inc.

Sa'adah, N., \& Primanda, Y. (2016). Hubungan keyakinan kemampuan diri (self-efficacy) terhadap perilaku perawatan kaki pada pasien diabetes mellitus. Yogyakarta: Universitas Muhammadiyah.

Safitri, I. N. (2013). Kepatuhan penderita diabetes mellitus tipe II ditinjau dari locus of control. Jurnal Ilmiah Psikologi Terapan. 1(2): 273.

Salistiyaningsih, W., Puspitawati, S \& Nugroho, D. K. (2011). Hubungan tingkat kepatuhan minum obat hipoglikemik oral dengan kadar glukosa darah pada pasien diabetes melitus tipe 2. Berita Kedokteran Masyarakat. (27): 219.

Sari, A. S. (2013). Analisa faktor-faktor yang mempengaruhi perawatan diri pasien diabetes melitus tipe 2 di Kecamatan Medan Johor. Skripsi. Medan: Fakultas Keperawatan Universitas Sumatra Utara

Sasagawa, M., Martzen, M. R., Kelleher, W. J., \& Wenner, C. A. (2008). Positive correlation between the usage of complementary and alternative medicine and internal health locus of control. Explore (NY). 4(1): 38-41. doi:10.1016/j.explore.2007.10.004 [Retrieved 27 May2017].

Schultz, D. P. \& Schultz, S. E. (2005). Theories of Personality. Ninth Edition. USA: Wadsworth

Septiady, Y. A. \& Suhana. (2015). Hubungan antara health locus of control dan self efficacy pada pasien gagal ginjal akut yang menjalani hemodialisa di Rumah Sakit Al-Islam Bandung. Prosiding Psikologi.

Sigurdardottir, A. (2005). Self-care in diabetes: model of factors affecting self-care. http://onlinelibrary.wiley.com/doi/10.1111/j.1365-

2702.2004.01043.x/epdf?r3_referer=wol\&tracking_action=preview_click\&show_checkout=1\&purchase_r eferrer=onlinelibrary.wiley.com\&purchase_site_license=LICENSE_DENIED [Retrieved 5 October 2016].

Smeltzer, S. C. dan Bare, B. G. (2001). Buku Ajar Keperawatan Medikal-Bedah Brunner dan Suddarth, Volume 2. Edisi 8. Jakarta: EGC.

Skinner, T. C., John, M., \& Hampson, S. E. (2000). Social support and personal models of diabetes as predictors of selfcare and well-being: a longitudinal study of adolescents with diabetes. Journal of Pediatric Psychology. 25(4): 257-268. Doi: https://doi.org/10.1093/jpepsy/25.4.257

Smet, B. (1994). Psikologi Kesehatan. Jakarta: PT. Gramedia Widiasarana Indonesia.

Sousa, V. D., Zauszniewski, J. A., Musil, C. M., Lea, P. J. P., \& Davis, S. A. (2005). Relationships among self-care agency, self-efficacy, self-care, and glycemic Control. An International Journal. 19 (3): 217-230. http://moscow.scihub.cc/752d5dd211d4c1cd4482e28c6319cafd/sousa2005.pdf [Retrieved 23 May 2017].

Sukma, T.R. (2012). Hubungan antara locus of control dengan stres kerja karyawan di CV. Duta Malang. Thesis. Universitas Islam Negeri Maulana Malik Ibrahim. 
Suls, J. and Wallston, K. A. (2003). Social Psychological Foundations of Health and Illness. Blackwell Publishing Ltd Sustrani, L., Alam, S., \& Hadibroto, L. 2004. Diabetes. Jakarta: PT. Gramedia Pustaka Utama

Taher, M., Bayat, Z. S., Zandi K. N., Ghasemi, E., Abredari, H., Karimy, M., \& Abedi, A. R. (2015). Correlation between compliance regimens with health locus of control in patients with hypertension. Med J Islam Repub Iran. 29:194. https://www.ncbi.nlm.nih.gov/pmc/articles/PMC4476223/pdf/MJIRI-29-194.pdf [Diakses pada 23 Mei 2017]

Tomky, D. M., \& Albuquerque. (2010). Self-monitoring of blood glucose. https://www.bd.com/resource.aspx?IDX=10250 [Retrieved 11 June 2017]

Toobert, D. J., Hampson, S. E., \& Glasgow, R. E. (2000). The summary of diabetes self-care activities measure: results from 7 studies and a revised scale. diabetes care. 23(7): 943.

Utomo, A. Y. S. (2011). Hubungan antara 4 pilar pengelolaan diabetes melitus dengan keberhasilan pengelolaan diabetes melitus tipe 2. http://eprints.undip.ac.id/32797/1/Acmad_Yoga.pdf [Retrieved 22 May 2017]

Wallston, B. S. \& Wallston, K. A. (1978). Locus of control and health: a review of the literature. Health Education Monographs Spring. 6: 107.

Wallston, K. A., Wallston, B. S. \& DeVellis R. (1978). Development of the Multidimensional Health Locus of Control (MHLC) Scales. Health Education Monographs. 6(2): 160.

Wallston, K. A., Stein, M. J., \& Smith, C. A. (1994). Form C of the MHLC Scales: A condition-specific measure of locus of control. Journal of Personality Assessment. 63(3): 534-553.

Widayati, N. (2015). Hambatan dan Strategi Koping dalam Manajemen Perawatan Diri Penderita Diabetes Melitus Tipe 2 di Wilayah Kerja Puskesmas Jember Kidul Kabupaten Jember. Jember: Universitas Jember.

World Health Organization. (2016). Diabetes Fact Sheet. http://www.who.int/mediacentre/factsheets/fs312/en/. [Retrieved 28 September 2016].

Xu, Y., Toobert, D., Savage, C., Pan, W., \& Whitemer, K. (2008). Factors influencing diabetes self-management in chinese people with type 2 diabetes. Research in Nursing \& Health. 31: 613-625. Doi: 0.1002/nur.20293 [Retrieved 23 May 2017].

Zahednezhad, H., Poursharifi, H., \& Babapour, J. (2011). Memory, health locus of control and adherence in type ii diabetic patients in Iran - Tabriz. Procedia - Social and Behavioral Sciences. 30: 2621-2624. doi: 10.1016/j.sbspro.2011.10.513 